ERC Working Papers in Economics 13/06

May/ 2013

\title{
Deunionization and Pay Inequality in OECD Countries: A Panel Granger Causality Approach
}

\author{
Ünal Töngür \\ Department of Economics, Middle East Technical University, \\ Ankara,TURKEY \\ E-mail: tongur@metu.edu.tr, \\ Phone: $+(90) 3122103090$
}

Adem Yavuz Elveren

Department of Economics, Sutcu Imam University,

Kahramanmaras, TURKEY

and

Department of Economics, Middle East Technical University, Ankara,TURKEY

E-mail: ademyavuzelveren@gmail.com

Phone: +(90) 3122102003 


\title{
Deunionization and Pay Inequality in OECD Countries:
}

\section{A Panel Granger Causality Approach}

\author{
Ünal Töngür ${ }^{1}$ \\ Middle East Technical University, Ankara, Turkey \\ tongur@metu.edu.tr \\ $\&$ \\ Adem Yavuz Elveren \\ Sutcu Imam University, Kahramanmaras, Turkey \\ ademyavuzelveren@gmail.com
}

\begin{abstract}
The impact of unionization on wage inequality has been examined by a vast literature. Focusing mostly on the US and the UK in time series analyses or on OECD countries in panel data analyses, a bulk of these studies have found a negative impact of deunionization (i.e. decline in the union density rate) on distribution of wages. By utilizing two inequality data sets both provided by the University of Texas Inequality Project this paper contributes to the literature, analyzing the causality relationship between deunionization and pay inequality for 24 OECD countries for the 1963-2000 period within a panel Granger structure. Our findings show not only that there is causality from union density to income inequality but also, perhaps more importantly, point out that there is causality running from income inequality to union density for various set of countries and time periods.
\end{abstract}

Key Words: Union membership, Pay Inequality, Income Inequality, Panel Granger

JEL Classification: C33, J31, J51

\footnotetext{
${ }^{1}$ Corresponding author: Department of Economics, Middle East Technical University, Ankara, Turkey. We would like to thank Hasan Dudu for his valuable comments.
} 


\section{Introduction}

The decline in unionization rates and increasing income inequality have been two remarkable patterns in many OECD countries during the era of globalization. The structural change driven by globalization and technological change has led to increasing inequality. A number of developed countries have reformed their labor markets in the past two decades as a response to globalization. Changing wage-setting mechanisms and deunionization are two of these institutional changes. Therefore, it is observed that deunionization and increasing inequality have gone hand in hand in the neoliberal period in many OECD countries.

The literature suggests three main reasons for deunionization: abandoning fullemployment policies, and less union- and labor-friendly labor market reforms since the early 1980s; change in industrial composition of production; and increasing competition among firms. The unions reduce wage inequality by standardizing wages among union members. That is, they increase wages for low skilled workers more than they do for skilled workers, improving the effect of the distribution of wages (Lewis 1986). In this sense, deunionization is considered one of the key factors behind increasing income inequality in general, and pay inequality in particular, across the world.

Scholars have paid significant attention to this phenomenon, investigating the effect of the fall of union density on increasing income inequality. Many time series and panel data studies have made evident an improving effect of the unions on the distribution of wage. However, to the best of our knowledge, there is no study that adopts a panel Granger causality method to analyze the possible relationship between union density and income inequality. This 
study aims at contributing to this literature by investigating this relationship with a panel Granger causality method.

This study is relevant for two reasons. First, it provides further evidence on the relationship between union density and income inequality by adopting a relatively recent panel Granger method for the first time. The second novelty of the study is to utilize two data sets, both provided by the University of Texas Inequality Project, which allows one to analyze a relatively larger time period of 1963-2000 for 24 OECD countries.

The next section briefly discusses the relationship between unionization and income inequality, and highlights the related empirical works. Section 3 introduces the methodology that we adopted. Following is Section 4, in which the data and model are presented, and Section 5 presents the results and discussion. Finally, the last section summarizes the findings.

\section{Deunionization and Income Inequality}

The decline in the unionization rates $^{2}$ and increasing pay/income inequality are two apparent trends for the majority of developed countries. One common fact that all major sources, such as Luxembourg Income Study (LIS), the United Nations World Income Inequality Database (WIID) and the University of Texas Inequality Project (UTIP), indicate is that inequality began rising in the early 1980s in OECD countries, sped up with the late 1980s, and slightly declined in the early 2000s (OECD 2012). Overall, inequality has risen in many OECD countries in the last decade, except for some highly unequal countries like Chile, Mexico and Turkey (OECD 2012).

\footnotetext{
${ }^{2}$ It is worth noting that there is some divergence in union density over time across countries rather than a convergence (Schnabel 2012). That is, while there is overall decline in unionization, the differences in unionization rates are increasing across countries (for a comprehensive review see Blanchflower 2006).
} 
Increasing inequality went hand-in-hand with the structural change driven by globalization and technological development. Since this technological change benefits highskilled workers at the expense of low-skilled ones, it can be considered as the principal factor behind the widening wage inequality (Acemoglu et al 2011; Acemoglu 2002). Another factor that contributes to this pattern during this era was a shift in the composition of jobs toward lower paid ones. For instance, women's employment has grown much faster than that of men. However, the fact that women typically work part-time and are paid less has contributed to the widening in wage gaps within the workforce (OECD 2011). Income distribution has deteriorated in parallel to increasing wage inequality. In fact, increasing labor income inequality has been the underlying reason for the increase in income inequality, as wages and salaries account for 75 per cent of household incomes of working age-adults (OECD 2012).

Most of the OECD countries have regulated their labor markets in the past two decades as a response to globalization. For instance, policy makers reduced the replacement rates of unemployment benefits and taxes on labor for low-income workers, and have improved employment protection legislation for workers with temporary contracts (OECD 2011). Wagesetting mechanisms have also changed in the past three decades. The trend of deunionization was another remarkable pattern across the OECD countries in this period.

Unionization is one of the important institutional factors that has an impact on the wage structure. The unions reduce wage inequality by standardizing wages among union members. On the other hand, they worsen wage inequality via crowding effect, as those who cannot find a job in unionized sectors move into non-unionized sectors, causing higher labor supply and therefore lowering wage levels in those sectors. However, unions also equalize the nonunion wage distribution by threatening union organization and enforcing the norms for fair pay (Western and 
Rosenfeld 2011). As a matter of fact, empirical literature shows that the wage compressing effect overbalances the deteriorating effect (Freeman 1980, 1984, Freeman and Medoff 1984, Card 1998; 2001, Card et al 2004, Metcalf et al 2001). Since the unions increase wages for less skilled workers more than they do for skilled workers, they have an improving effect on the distribution of wages (Reynolds 1967, Lewis 1986, Lemieux 1993, Chamberlain 1994, DiNardo et al 1996, Card 1996, Kaufaman 2002, Blanchflower and Bryson 2003). Therefore, one reason behind the increasing wage inequality is the decline in the union membership over the period (Card 2001, Acemoglu et al 2001).

Three main reasons for deunionization have been noted in the literature (Carlin and Soskice 1990, Acemoglu et al 2001, Schmitt and Mitukiewicz 2012). First, the neoliberal paradigm in the early 1980s created an extremely negative environment for unions with the abandonment of full-employment policies. Since that time, labor laws across the world have become much less union friendly, and unionizing new establishments has become harder (Blanchflower 2006). Second, there is a shift in the industrial composition of production, toward where organizing union activity is more expensive (Checchi and Visser 2005, Visser 2006, Schnabel and Wagner 2007, Ebbinghaus et al 2011 cited in Schnabel 2012). Third, the product market competition among firms has increased (Acemoglu et al 2001).

In addition to these three causes of deunionization, Acemoglu et al (2001) also emphasizes the role of technology. With increasing technology there is a shift in demand for skilled workers, and the labor supply does not adjust quickly enough to this change. In this context, Acemoglu et al (2001) argue that skill-biased technical change is not just a cause for rising inequality, but also for deunionization. Increasing productivity differentials weaken the coalition between skilled and unskilled workers over joining the trade unions since the improved 
outside opportunities (i.e. the competitive market return) reduce the incentives of skilled workers to join the union. That is, deunionization increases the original impact of skill-biased technical change on inequality as unions no longer compress the wages (Acemoglu et al 2001: 24).

Checchi et al (2007), following the argument raised by Acemoglu et al (2001), states that besides the common view that decline in unionization (i.e. less member and/or lower bargaining coverage) increases pay inequality (Alderson and Nielsen 2002, DiNardo et al 1996, Freeman 1980, Rueda and Pontusson 2000, Wallerstein 1999, cited in Checchi et al 2007) change in pay inequality also affects the incentive to join the unions. The reason is the fact that more earnings diverge from the median earnings, since the unions relatively serve more for the interest of intermediate earners than for those of high and low earners. They argue that no matter what the cause (i.e. skill-biased change, globalization or migration) increasing pay inequality reduces incentives to join a union (Checchi et al 2007: 22).

There is a growing body of literature on the effect of deunionization on pay/income inequality (see Blanchflower 2006, Stennek 2012 and Schnabel 2012 for comprehensive reviews on the other aspects of the (de)unionization). For example, Mosher (2007), Volscho and Fullerton (2005), Western and Rosenfeld (2011), Gosling and Lemieux (2001), Freeman (1983), DiNardo et al. (1996), Card (1992; 2001), Freeman (1993), Frandsen 2012 on the US, Lemieux (1998) on Canada, DiNardo and Lemieux (1997), Lemieux (1993) on the US and Canada, Bell and Pitt (1998) and Machin (1997) on UK, Card et al (2004) on the US and the UK, Checci and Pagani (2004) on Italy, and Utlu et al (mimeo) on Turkey show the deteriorating effect of deunionization on the distribution of wage. 
Aside from those single-country or a-few-country comparison studies, there are also several panel studies with a larger number of countries that find a negative ${ }^{3}$ relationship between union density/membership and pay/income inequality, such as Wallerstein (1999) for 16 OECD countries during the 1980-1992 period, Rueda and Pontusson (2000) (and Pontusson et al 2003 in a similar study) for the same countries of Wallerstein (1999) during the 1973-1995 period by controlling further economic conditions, Koeniger et al (2007) for fewer (i.e. 11) countries during the 1973-1998 period by considering more variables on the labor market, Bradley et al (2003) for 14 advanced countries for various survey years for the 1970s, 80s and 90s, Calderon et al (2004) for 121 countries during the 1970-2000 period, Checchi and Garcia-Penalosa (2008) for 17 OECD countries during the 1969-2004 period, Chintrakarn (2011) for 48 states of the US for the period of 1988-2003, Georgiou (2012) for the western European countries during the 1999-2008 period, and Kahn (2000) for 15 OECD countries for the period of 1985-1994, and Doerrenberg and Peichl (2012) during the period 1981-2005 for OECD countries.

However, to the best of our knowledge, there is no study that investigates the causality between the variables in question. Also, there is ambiguity in the direction of causality. Considering these facts, this study attempts to fill this gap by investigating causality between union density and two different measures of income inequality in a panel data context by using the method by Hurlin and Venet (2001).

\footnotetext{
${ }^{3}$ However, Baccaro (2008) finds no improving effect of unionization on income inequality for 51 Advanced, Central and Eastern European, Latin American, and Asian countries for the period of 1989-2005, except for Central and Eastern European, and Volscho (2008) found that by the late 1990s between the states of the US union density has positive impact on income inequality.
} 


\section{Methodology}

In this study, we employ the Granger causality method, originating from the seminal work of Granger (1969). The method is broadly used to analyze causal effects between time series variables. The logic is that a cause cannot come after an effect, which means that the past can only predict the future; not vice versa. Therefore, the causal relationship between two variables can be determined by examining the way they move with respect to each other over time. In that sense, a variable $x$ is said to Granger-cause another variable $y$, if future values of $y$ can be predicted better by using past values of $x$ and $y$, than by using the past values of $y$ only.

The standard Granger causality is not appropriate for panel data. Over the past few decades, some Granger-causality tests have been developed to incorporate panel data. Hurlin and Venet (2001) pointed out that a panel data dimension provides both cross-sectional and time series information and a large number of observations to utilize. Moreover, it substantially improves the efficiency of Granger causality tests by increasing the degrees of freedom and reducing the collinearity among explanatory variables (Greene, 2008; Baltagi, 2005). Moreover, panel data allows for more flexibility in the modeling of the behavior of cross-sectional units than conventional time series analysis (Greene, 2008).

There are two main approaches to analyze Granger causality in a panel data context (Erdil and Yetkiner 2009). First, following Holtz-Eakin et al. (1985), one treats the autoregressive coefficients and slope coefficients as variables in a panel VAR model. Similar methods have been developed or utilized by -inter alia- Hsiao (1986), Holtz-Eakin et al. (1988), Hsiao (1989), Weinhold (1996), Weinhold (1999), Nair-Reichart and Weinhold (2001) and Choe (2003). The second approach, where the autoregressive coefficients and slope coefficients are 
treated as constants, is developed by Hurlin and Venet (2001), Hurlin (2004a, 2004b), and Hansen and Rand (2006). There are some studies that adopt Hurlin and Venet (2001)'s approach to test causality for panel data (e.g, Hoffman, et al., 2005; Hood III, et al, 2008, Erdil and Yetkiner, 2009).

In this study, we employ the second approach since we focus on a large number of crosssection units but relatively short time periods, and we also consider a small number of countries for a larger time period for comparison. ${ }^{4}$ Following Hurlin and Venet (2001), we consider two covariance stationary variables observed on $T$ periods and on $N$ cross-section units. In the context of Granger (1969) causality procedure, the variable $x_{i, t}$ is causing another variable $y_{i, t}$ if future values of $y_{i, t}$ could be predicted better by using past values of $x_{i, t}$ and $y_{i, t}$, than if only the information of $y_{i, t}$ (i.e., apart from $x_{i, t}$ ) had been used. We take into account linear predictors only because it may not be possible to use optimum predictors completely. Considering a timestationary VAR representation adapted for a panel setting, we estimate the following model $^{5}$ :

$$
y_{i, t}=\sum_{k=1}^{p} \gamma^{k} y_{i, t-k}+\sum_{k=1}^{p} \beta_{i}^{k} x_{i, t-k}+v_{i, t}
$$

with $\dot{i} \in[1, N]$ and $v_{i, t}=\alpha_{i}+\varepsilon_{i, t}$, where $\alpha_{i}$ are individual effects and $\varepsilon_{i, t}$ are i.i.d. $\left(0, \sigma_{\varepsilon}^{2}\right) \cdot y_{i, t}$ and $x_{i, t}$ are covariance stationary variables. The autoregressive coefficients $\gamma^{k}$ and regression

\footnotetext{
${ }^{4}$ The second approach allows the analysis not only for large $\mathrm{N}$ and small $\mathrm{T}$, but also for small $\mathrm{N}$ and large $\mathrm{T}$. In fact, Hurlin and Venet (2001) provides an extension of panel Granger causality also for large $\mathrm{N}$ and small $\mathrm{T}$.

${ }^{5}$ Hurlin and Venet (2001) also consider the possibility of instantaneous effects of $x_{i, t}$ on $y_{i, t}$ (includes the current value of $x$ as a regressor). However, we ignore this possibility since we are not concerned about an instantaneous relationship (and because it is unlikely that there is instantaneous effect between variables in our question); therefore we would prefer to focus on exploring to what extent the past values of $x_{i, t}$ could be of helping in predicting $y_{i, t}$. Moreover, our definition of the best linear predictor is a straightforward extension of the conventional version of Granger causality method.
} 
coefficient slopes $\beta_{i}^{k}$ are assumed to be constant over time. Particularly, $\gamma^{k}$ is assumed to be identical across individuals, while $\beta_{i}^{k}$ may differ across individuals, and $p$ is the number of lags. The residuals are assumed to satisfy the standard properties, i.e., they are independently, identically, and normally distributed, and free from heteroscedasticity and autocorrelation. Hence, the model above is a panel data model with fixed coefficients and established for Granger causality in a panel data context.

The conventional Granger causality tests raise two critical issues for a panel data case, both dealing with the potential heterogeneity of the individual cross sections. The first source of heterogeneity is cross sectional variation due to the distinctive intercepts; such heterogeneity may be addressed with a fixed effects model (i.e. it is controlled by introduction of individual effects $\alpha_{i}$ in the model). The more crucial case is where heterogeneous slope coefficients should be considered (i.e. should be controlled by introducing individual dimension for regression slopes $\beta_{i}^{k}$ in the model). The second source of heterogeneity affects the causality relationships. For instance, for some individuals the introduction of past values of $x$ may improve the forecast on $y$, whereas for others there may be no improvement. Therefore, we should distinguish two subgroups of individuals according to the causality relationships between $x$ and $y$. If this heterogeneity is not considered, the test of causality hypothesis may lead to a fallacious conclusion concerning the relative size of the two subgroups. In a nutshell, the Granger causality for panel data sets should consider the different sources of heterogeneity of the data-generating process. In this study, following Hurlin and Venet (2001), both sources of heterogeneity mentioned above are controlled. 
If we consider model (1), the general definitions of causality imply testing for linear restrictions on these coefficients. The procedure has three main steps, which are related to the homogeneous non-causality (HNC), homogeneous causality (HC) and heterogeneous noncausality (HENC) hypotheses.

HNC refers to the case in which there is no linear causality between dependent variable $y_{i, t}$ and explanatory variable $x_{i, t}$ for any cross section (the null hypothesis states non-existence of causal relationships across all cross sections, $N$ ).

The null and alternative hypotheses for the HNC case are:

$$
\begin{aligned}
& H_{0}: \beta_{i}^{k}=0, \forall i \in[1, N], \forall k \in[1, p] \\
& H_{a}: \exists(i, k), \beta_{i}^{k} \neq 0
\end{aligned}
$$

To test these $N p$ linear restrictions, the following Wald statistic is computed:

$$
F_{\text {hnc }}=\frac{\left(R S S_{2}-R S S_{1}\right) /(N p)}{R S S_{1} /[N T-N(1+p)-p]}
$$

where $R S S_{2}$ denotes the sum of squared residuals obtained under $H_{0}$, and $R S S_{1}$ denotes the sum of squared residuals produced by the unrestricted model in equation (1). If we assume the individual effects are fixed, both $R S S_{1}$ and $R S S_{2}$ are given by the RSS obtained from maximum likelihood estimation (MLE) that corresponds in this case to the fixed effects (FE) estimator.

HC means that there exists causality between $y_{i, t}$ and $x_{i, t}$ for all cross sections (the null hypothesis states existence of causal relationships across all cross sections, $N$ ).

The null and alternative hypotheses of the $\mathrm{HC}$ case are: 


$$
\begin{aligned}
& H_{0}: \forall k \in[1, p], \beta_{i}^{k}=\beta^{k}, \forall i \in[1, N] \\
& H_{a}: \exists k \in[1, p], \exists(i, j) \in[1, N], \beta_{i}^{k} \neq \beta^{k}
\end{aligned}
$$

with the F-statistic being:

$$
F_{h c}=\frac{\left(R S S_{3}-R S S_{1}\right) /[p(N-1)]}{R S S_{1} /[N T-N(1+p)-p]}
$$

where $\mathrm{RSS}_{3}$ corresponding to the realization of the sum of residual squares obtained when one imposes the homogeneity for each lag $k$ of the coefficients associated to the variable $x_{i, t-k}$. As for the HNC hypothesis test, if we assume that individual effects are fixed under $H_{0}$ and $H_{a}$, the MLE estimator corresponds to FE estimator.

HENC refers to the situation in which at least one cross section unit does not indicate a causality relationship between $y_{i, t}$ and $x_{i, t}$ (the null hypothesis states non-existence of causal relationship for each cross section unit).

The null and alternative hypotheses of the HENC case are:

$$
\begin{aligned}
& H_{0}: \exists i \in[1, N], \forall k \in[1, p], \beta_{i}^{k}=0 \\
& H_{a}: \forall i \in[1, N], \exists k \in[1, N], \beta_{i}^{k} \neq 0
\end{aligned}
$$

For that, we compute $N$ statistics:

$$
F_{\text {henc }}^{i}=\frac{\left(R S S_{2, i}-R S S_{1}\right) / p}{R S S_{1} /[N T-N(1+2 p)+p]}
$$


where $R S S_{2, i}$ denotes the sum of residual squares obtained from model (1) when one imposes $\beta_{i}^{k}=0, \forall k \in[1, p]$ for each $i$. This means that $x_{i, t-p}$ of the cross section unit in question is excluded from the panel for the restricted model. These $N$ cross-sectional tests allow to us to identify the individuals for which there are no causality relationships.

In summary, the hypothesis tests proceed as follows: One first tests the HNC hypothesis, and then the $\mathrm{HC}$ hypothesis if the $\mathrm{HNC}$ hypothesis is rejected. If the HC hypothesis is also rejected, then the HENC hypothesis is tested. If the HENC is accepted, there exists an individual in question for which $x_{i, t}$ does not Granger cause $y_{i, t}$; whereas if the HENC is rejected, causal relationship is present for the cross section unit in question. Intrinsically, HENC hypothesis could be considered as the consequence of the heterogeneity of the data-generating process (see Figure A1 in the Appendix for this procedure).

It is worth noting that for micro panels, where there are a large number of individuals $(\mathrm{N})$ observed over a short period of time $(\mathrm{T})$, the fixed effects estimator of the coefficients of endogenous lagged variables is biased and inconsistent (Nickell, 1981). MLE for the dynamic fixed effects model remains biased with the introduction of exogenous variables when $\mathrm{T}$ is small. In this situation, the estimators of coefficients of exogenous variables are also biased (Kiviet, 1995). Nickell (1981) also showed that the presence of exogenous variables modifies the size of the bias on the coefficients of the lagged endogenous variables. Therefore, these issues imply that the Wald statistics concerning Granger causality tests do not have a standard distribution under the null hypothesis when $\mathrm{T}$ is small ${ }^{6}$. Moreover, one may still favor the FE estimator, arguing that its bias may not be large in this case. Hurlin and Venet (2001) assert that the test statistic obtained from the asymptotic distribution of $F_{h n c}$ converges to non-central parameters

\footnotetext{
${ }^{6}$ On the other hand, Judson and Owen (1999) show that the FE estimator bias decreases with T.
} 
(non-standard critical values) when $\mathrm{T}$ is small, whereas it converges to central parameters (standard critical values) when $\mathrm{T}$ is large. Hurlin (2004a) computed different critical values for non-centered $\mathrm{F}$ distribution by implementing a Monte Carlo study to consider dynamic panel bias effect. His empirical critical values are higher than the theoretical ones. When $\mathrm{T}$ is small, using those simulated critical values in Hurlin (2004a) clearly reduced the risk of rejecting an incorrect hypothesis. Although we acknowledge that dynamic panel bias in our case is not large, we still adopt the dynamic FE estimator procedure in Hurlin and Venet (2001) as we avoid bias problem by using non-centered critical values. In sum, dynamic panel bias is in favor of the causality hypothesis in our case.

\section{Data and Model}

In our empirical analysis, which is based on country-level annual data, we attempt to test the causality between union density and income inequality. We utilize the most commonly used measure for union bargaining power in the literature, the trade union density which is provided by the OECD during the period of 1963-2001. Union density measures the net union membership as a percentage of all wage earners.

We utilize two inequality data sets. The first set, UTIP-UNIDO, is provided by the University of Texas Inequality Project (UTIP), based on the United Nations International Development Organization (UNIDO) Industrial Statistics. UTIP-UNIDO data set is constructed by calculating the between-group Theil's T statistic over the UNIDO manufacturing pay data provided, according to the International Standard Industrial Classification (Galbraith and Conceição, 2001).

The between-group $\left(T^{B}\right)$ of Theil's T statistic can be stated as 


$$
T^{B}=\sum_{i=1}^{n}\left\{\left(\frac{p_{i}}{P}\right) *\left(\frac{y_{i}}{\mu}\right) * \ln \left(\frac{y_{i}}{\mu}\right)\right\}
$$

where $\mathrm{i}$ indexes groups, $\mathrm{p}_{\mathrm{i}}$ is the population of group $\mathrm{i}, \mathrm{P}$ is the total population, $\mathrm{y}_{\mathrm{i}}$ is the average wage in group $i$, and $\mu$ is the average wage of the entire population (Theil 1972).

The second data set, Estimated Household Income Inequality (EHII), is also provided by the UTIP. The group calculates EHII by combining the UTIP-UNIDO data set and DeiningerSquire (1996) data set in the Gini format based on some statistical methods. These pay inequality indices cover 156 countries during the 1963-2002 period (see the UTIP and Galbraith \& Kum 2005 for details, and Galbraith 2009; 2012 for comprehensive reviews of the studies utilizing these data sets).

Since we deal with balanced panel cases for causality testing procedures in Hurlin and Venet (2001), we limited our data set with those countries which have sufficient data of union density and inequality. Also, we excluded those who have less than 12 observations because of two reasons. First, although we have a large $N$-small $T$ data set, we would like to consider the dynamics of variables in a relatively larger time period. Second, due to the lag structure of the models, degrees of freedom have to be taken into account. Therefore, we consider two alternative time periods for the models by restricting the data into a balanced panel, one with large $\mathrm{N}$ and small $\mathrm{T}$ in our case, and vice versa for comparison. Specifically, one set covers 13 countries during the period of 1963-1999, and the other covers 23 countries for a relatively shorter time period of 1986-1998 for union density-Theil model. Similarly, for the case of causality between union density and EHII, one data set includes 12 countries from 1963 to 2000, 
and the other covers 23 countries through the 1986-1997 period. Our data set has 24 OECD countries in $\operatorname{total}^{7}$. Descriptive statistics of the variables are provided in the Appendix (see Table A1).

Table 1: Results of Panel Unit Root Tests

\begin{tabular}{|c|c|c|c|c|c|c|}
\hline \multicolumn{7}{|c|}{ LEVEL } \\
\hline & \multicolumn{3}{|c|}{ with intercept } & \multicolumn{3}{|c|}{ with intercept and trend } \\
\hline & UD & THEIL & EHII & UD & THEIL & EHII \\
\hline LLC & $-4.1127 * *$ & -0.6711 & $-2.6905 * *$ & $-24.3511 * * *$ & -1.2522 & $-5.3603 * * *$ \\
\hline Breitung & 0.3435 & $-1.9777 * *$ & -0.2300 & 0.7645 & 0.8109 & -1.0741 \\
\hline IPS & 2.2152 & 0.7382 & 0.0269 & $-3.0349 * * *$ & 2.4570 & -0.4343 \\
\hline MW & 31.6342 & 47.3198 & 56.6999 & 46.4875 & 42.9830 & 64.7418 \\
\hline Choi & 50.2224 & $65.5255^{*}$ & $91.6057 * * *$ & 50.4594 & 53.7438 & $121.3104 * * *$ \\
\hline \multicolumn{7}{|c|}{ FIRST DIFFERENCE } \\
\hline & \multicolumn{3}{|c|}{ with intercept } & \multicolumn{3}{|c|}{ with intercept and trend } \\
\hline & $\Delta \mathrm{UD}$ & $\Delta$ THEIL & $\Delta \mathrm{EHII}$ & $\Delta \mathrm{UD}$ & $\Delta$ THEIL & $\Delta$ EHII \\
\hline LLC & $-15.6541 * * *$ & $-3.0756 * * *$ & $-9.1796 * * *$ & $-19.7335^{* * * *}$ & $-5.1994 * * *$ & $-11.0690 * * *$ \\
\hline Breitung & $-4.3270 * * *$ & $-3.7983 * * *$ & $-2.8919 * * *$ & $-1.6077 * *$ & $-1.5642 * *$ & $-3.6602 * * *$ \\
\hline IPS & $-4.5585 * * *$ & $-2.7792 * * *$ & $-5.7475 * * *$ & $-5.2771 * * *$ & $-1.2756^{*}$ & $-4.2910 * * *$ \\
\hline MW & $182.1242 * * *$ & $106.0021 * * *$ & $160.6960 * * *$ & $274.4664 * * *$ & $81.8097 * * *$ & $153.6554 * * *$ \\
\hline Choi & $91.0023 * * *$ & $266.2572 * * *$ & $404.5613 * * *$ & $129.6578 * * *$ & $217.6571 * * *$ & $354.1452 * * *$ \\
\hline
\end{tabular}

Significance denoted by $* * *$ at $1 \%, * *$ at $5 \%$ and $*$ at $10 \%$ level.

Notes: LLC refers the bias-adjusted $t$ statistic for Levin-Lin-Chu unit root test; Breitung refers lambda statistic for Breitung unit root test; IPS refers W-t-bar statistic for Im-Pesaran-Shin unit root test; MW refers the chi2 statistic for Maddala-Wu unit root test (Fisher-type test using the ADF test); and Choi refers the P statistic for Choi unit root test (Fisher-type test using the PP test).

Since we take into account time stationary VAR models, it is clear that the validity of the statistical estimates depends on stationarity of the data series. In other words, the variables in question should not include a unit root. We employ several panel unit root tests that are extensively used for panel data. Two of these tests, the Levin-Lin-Chu panel unit root test (Levin, Lin and Chu; 2002) and Breitung panel unit root test (Breitung; 2000 and 2005) assume a

\footnotetext{
${ }^{7}$ Although in each analyses (i.e. with Theil and EHII) 23 countries are included, the data of Japan is only available for Theil and one for Belgium is available for EHII, making 24 countries in total.
} 
common unit root for all panel members. The other three tests, the Im-Pesaran-Shin panel unit root test (Im, Peseran, Shin; 2003), Maddala-Wu panel unit root test (Fisher-type test using ADF test; Maddala and Wu 1999), and Choi panel unit root test (Fisher-type test using Phillips Perron test Choi 2001) allow for individual unit roots for panel members. As illustrated in Table 1, while most of the tests lead us to accept the existence of unit root at levels for all variables, all tests indicate that the first difference series of all variables are stationary ${ }^{8}$. Hence, we use first differenced values of all variables in the models as they are stationary.

We analyze two alternative causality effects between union density and income inequality. The first option is to examine the causality between union density and Theil index. The following two time stationary VAR models are estimated for each of the time periods (i.e., 1963-1999 and 1986-1998), separately:

$$
\begin{aligned}
& \Delta U D_{i, t}=\sum_{k=1}^{p} \gamma^{k} \Delta U D_{i, t-k}+\sum_{k=1}^{p} \beta_{i}^{k} \Delta T H E I L_{i, t-k}+v_{i, t} \\
& \Delta \text { THEIL }_{i, t}=\sum_{k=1}^{p} \gamma^{k} \Delta T H E I L_{i, t-k}+\sum_{k=1}^{p} \beta_{i}^{k} \Delta U D_{i, t-k}+v_{i, t}
\end{aligned}
$$

Rather than choosing a certain lag length based on information criteria, we compute and report all relevant statistics for one, two and three lags in order to assess the sensitivity of the results of our models to the choice of the common lag-order. The second and the third lags are used to investigate a possible long run relationship between the variables. However, considering more than three lags would lead not only to the degrees of freedom problem for all models, but would also lack a theoretical basis.

\footnotetext{
${ }^{8}$ These findings are consistent with Lin and Ali (2009), who also use Theil and EHII for the1987-1999 period.
} 
In order to examine causality between union density and income inequality, the other alternative is to analyze causality between union density and EHII index. The following time stationary VAR two models are estimated for each of the time periods (i.e., 1963-2000 and 19861997):

$$
\begin{aligned}
& \Delta U D_{i, t}=\sum_{k=1}^{p} \gamma^{k} \Delta U D_{i, t-k}+\sum_{k=1}^{p} \beta_{i}^{k} \Delta E H I I_{i, t-k}+v_{i, t} \\
& \Delta E H I I_{i, t}=\sum_{k=1}^{p} \gamma^{k} \Delta E H I I_{i, t-k}+\sum_{k=1}^{p} \beta_{i}^{k} \Delta U D_{i, t-k}+v_{i, t}
\end{aligned}
$$

We estimate firstly (8) and (9) for the causality between union density and Theil; then we perform the testing procedure (test homogenous non-causality, HNC, homogenous causality, HC, and heterogeneous non-causality, HENC). Then we repeat the same exercises for model (10) and (11) for the causality between union density and EHII.

\section{Results and Discussion}

The right hand side of Table 2 presents the results of the HNC and HC tests for both directions of causality for each set of countries. Regarding causality from union density to inequality, while the HNC test statistic is statistically significant at one lag during the period 1963-1999 with 13 countries for Theil, and at three lags during the period 1963-2000 with 12 countries for EHII; it is statistically significant at all three lags for Theil (during the period of 1986-1998 with 23 countries), and only at three lags for EHII (during the period of 1986-1997 with 23 countries). This allows us to reject the null hypothesis, suggesting that for at least one country, there is statistical evidence that union density Granger causes inequality. 
The left hand side of Table 2 shows the HNC statistics used to examine the hypothesis that inequality Granger causes union density. Accordingly, the HNC test statistic indicates that there is a significant Granger causality for Theil at one and three lag, only during the 1986-1998 period. Regarding EHII, on the other hand, the HNC test statistic is statistically significant at all three lags during the 1963-2000 period and at three lags during the 1986-1997 period.

Table 2: Test Results for Homogeneous Non-Causality (HNC) and Homogeneous Causality (HC)

\begin{tabular}{|c|c|c|c|c|c|c|c|}
\hline \multicolumn{8}{|c|}{ Union Density and Theil } \\
\hline & & \multicolumn{3}{|c|}{ Theil $\rightarrow$ UD } & \multicolumn{3}{|c|}{ UD $\rightarrow$ Theil } \\
\hline & & $t-1$ & $t-2$ & $t-3$ & $t-1$ & $t-2$ & $t-3$ \\
\hline \multirow{2}{*}{$\begin{array}{l}1963-1999 \\
\text { (13 countries) }\end{array}$} & $\mathrm{HNC}$ & 0.9404 & 0.8946 & 1.2828 & $2.2562 * * *$ & 1.0455 & 1.2472 \\
\hline & $\mathrm{HC}$ & 0.8095 & 0.8372 & 1.2323 & $2.2059 * * *$ & 1.0065 & 1.2546 \\
\hline \multirow{2}{*}{$\begin{array}{l}1986-1998 \\
(23 \text { countries })\end{array}$} & $\mathrm{HNC}$ & $1.4791^{*}$ & 1.2369 & $1.5475^{* *}$ & $1.6446^{* *}$ & $1.5548 * *$ & $1.7812 * * *$ \\
\hline & $\mathrm{HC}$ & $1.5330^{*}$ & 1.2416 & $1.5698 * *$ & $1.7018^{* *}$ & $1.5647 * *$ & $1.7088^{* * *}$ \\
\hline \multicolumn{8}{|c|}{$\underline{\text { Union Density and EHII }}$} \\
\hline & & \multicolumn{3}{|c|}{$\mathrm{EHII} \rightarrow \mathrm{UD}$} & \multicolumn{3}{|c|}{ UD $\rightarrow$ EHII } \\
\hline & & $t-1$ & $t-2$ & $t-3$ & $t-1$ & $t-2$ & $t-3$ \\
\hline \multirow{2}{*}{$\begin{array}{l}1963-2000 \\
(12 \text { countries })\end{array}$} & $\mathrm{HNC}$ & $1.6328^{*}$ & $1.4951^{*}$ & $1.4930 * *$ & 0.7054 & 0.9427 & $1.7676 * * *$ \\
\hline & $\mathrm{HC}$ & 1.1557 & 1.2800 & 1.3165 & 0.7418 & 0.7080 & $1.5195^{* *}$ \\
\hline \multirow{2}{*}{$\begin{array}{l}\text { 1986-1997 } \\
\text { (23 countries) }\end{array}$} & $\mathrm{HNC}$ & 1.2023 & 0.3497 & $1.9855^{* * *}$ & 0.9451 & 0.2205 & $2.0445^{* * * *}$ \\
\hline & $\mathrm{HC}$ & 1.2541 & 0.2869 & $2.0461 * * *$ & 0.9703 & 0.1587 & $1.9087 * * *$ \\
\hline
\end{tabular}

Significance denoted by $* * *$ at $1 \%, * *$ at $5 \%$ and $*$ at $10 \%$ level.

The HC hypothesis is designed to examine the homogeneity of the causal relationship. In order to test whether union density Granger causes inequality for all countries, we compute HC test statistics. Failure to reject HC hypothesis shows that the causal process is homogeneous for all countries. We need to go on the testing procedure since HC statistics, which are calculated for significant $\mathrm{HNC}$, confirm that none of the causality relationships are homogenous for either union density to Theil or to EHII, for both set of countries. However, regarding causality from inequality to union density, HC statistics are significant only during the 1986-1998 period (in 
Theil) and 1986-1997 period (in EHII). In sum, we can reject HC for the relationships in question; we need to go on with the next test procedure to determine the heterogeneity of the causal process across the countries for significant HC statistics that depend on the lag structures.

Table 3: Test Results for Heterogeneous Non-Causality (HENC): From Union Density to Inequality

\begin{tabular}{|c|c|c|c|c|c|c|}
\hline period & 1963-1999 & 1986-1998 & 1986-1998 & $1986-1998$ & $1963-2000$ & 1986-1997 \\
\hline causality & $U d \rightarrow$ Theil & $U d \rightarrow$ Theil & $U d \rightarrow$ Theil & $U d \rightarrow$ Theil & $U d \rightarrow E H I I$ & $U d \rightarrow E H I I$ \\
\hline lag & $t-1$ & $\mathrm{t}-1$ & $t-2$ & $t-3$ & $t-3$ & $\mathrm{t}-3$ \\
\hline Australia & 0.0589 & 0.0249 & 0.0981 & 0.0833 & 0.1301 & $2.5749^{*}$ \\
\hline Austria & 0.9199 & 0.1739 & 0.1595 & 0.4461 & 0.4653 & 0.0705 \\
\hline Belgium & & & & & & 1.0409 \\
\hline Canada & 0.3046 & 0.1378 & 0.0492 & 0.0560 & 0.3112 & 0.0346 \\
\hline Chile & & $3.2768^{*}$ & $2.7061 *$ & $2.7864 * *$ & & $2.7048 * *$ \\
\hline Denmark & & 0.0058 & 0.0008 & 0.0297 & & 0.4894 \\
\hline Finland & 0.0000 & 0.0738 & 0.0371 & 0.0335 & $4.9552 * * *$ & 0.7076 \\
\hline France & & 0.0016 & 0.0143 & 0.0113 & & 0.2809 \\
\hline Germany & 0.3349 & 0.0612 & 0.1410 & 0.1603 & 1.5623 & 1.0496 \\
\hline Greece & & 0.9663 & 0.5974 & 0.4238 & & 0.7315 \\
\hline Ireland & $25.8557 * * *$ & $14.5790^{* * * *}$ & $12.0648 * * *$ & $10.4353 * * *$ & $4.6399 * * *$ & 1.2062 \\
\hline Israel & & 0.0045 & 0.1198 & 0.5430 & & 0.8710 \\
\hline Italy & & 0.0160 & 0.0654 & 0.1999 & & 1.6069 \\
\hline Japan & 0.4108 & $9.5863 * * *$ & $6.4141 * * *$ & $6.6826 * * *$ & & \\
\hline Korea & 0.0052 & 0.0693 & 0.0188 & 0.7080 & 1.2046 & 0.0986 \\
\hline Luxembourg & & 0.0217 & 0.4962 & 0.1238 & & 0.2094 \\
\hline Netherlands & 0.3403 & 0.0000 & 0.0033 & 0.0136 & 1.5295 & 0.7880 \\
\hline New Zealand & & 0.4146 & $2.3235^{*}$ & 1.7040 & & 1.4829 \\
\hline Norway & 0.1888 & 0.0050 & 0.0163 & 0.0260 & $2.9902 * *$ & $4.0080 * * *$ \\
\hline Spain & & 0.1496 & 0.1315 & 0.1159 & & $2.6063 * * *$ \\
\hline Sweden & 0.0023 & 0.0098 & 0.0047 & 0.0033 & 1.5310 & 0.8146 \\
\hline Turkey & & $5.7613 * *$ & $5.0516^{* * *}$ & 3.8736 ** & & 1.2593 \\
\hline United Kingdom & 0.0242 & 0.1877 & 0.0868 & 0.0635 & 0.3752 & $5.2172 * * *$ \\
\hline United States & 0.0000 & 0.0091 & 0.0200 & 0.0314 & 0.0990 & 0.0088 \\
\hline
\end{tabular}

Significance denoted by $* * *$ at $1 \%, * *$ at $5 \%$ and $*$ at $10 \%$ level.

At the final step, we test the HENC hypothesis in order to determine countries that have causality. Rejection of HENC hypothesis shows the existence of a causal relationship for a 
certain country in our sample. In Table 3, HENC results indicate that for Chile, Ireland, Japan, New Zealand, and Turkey, union density Granger causes Theil pay inequality; for Australia, Chile, Finland, Ireland, Norway, Spain, and the UK, union density causes EHII.

Table 4: Test Results for Heterogeneous Non-Causality (HENC): From Inequality to Union Density

\begin{tabular}{|l|l|l|l|}
\hline \multicolumn{1}{|r|}{ Period } & \multicolumn{1}{|c|}{$1986-1998$} & \multicolumn{1}{c|}{$1986-1998$} & \multicolumn{1}{c|}{$1986-1997$} \\
\hline Countriables & \multicolumn{1}{|c|}{ Theil $\rightarrow$ Ud } & Theil $\rightarrow$ Ud & EHII $\rightarrow$ Ud \\
\hline Australia & \multicolumn{1}{|c|}{$\mathrm{t}-1$} & \multicolumn{1}{c|}{$\mathrm{t}-3$} & \multicolumn{1}{c|}{$\mathrm{t}-3$} \\
\hline Austria & 0.0011 & 0.2389 & 0.2885 \\
\hline Belgium & 0.0019 & 0.1110 & 0.2138 \\
\hline Canada & & & 0.1427 \\
\hline Chile & 0.0147 & 2.0494 & 1.7697 \\
\hline Denmark & 1.0849 & $2.5373^{*}$ & 1.5244 \\
\hline Finland & 0.1438 & 1.4626 & 1.2157 \\
\hline France & 0.0112 & 0.3275 & 1.6235 \\
\hline Germany & 0.0018 & 0.0075 & 0.0208 \\
\hline Greece & 1.1366 & 1.0721 & $2.4128^{*}$ \\
\hline Ireland & $3.7292^{*}$ & 1.0502 & $2.1646^{*}$ \\
\hline Israel & 2.4576 & 0.9195 & 1.2019 \\
\hline Italy & $14.1605^{* * *}$ & $7.4605^{* * *}$ & $7.6553^{* * *}$ \\
\hline Japan & 0.1669 & 0.1574 & 0.0661 \\
\hline Korea & 0.0004 & 0.0058 & \\
\hline Luxembourg & $3.2167 *$ & 0.1982 & 0.1273 \\
\hline Netherlands & 0.4911 & 0.7082 & 0.1390 \\
\hline New Zealand & 0.7812 & 0.1528 & 0.2481 \\
\hline Norway & 2.2478 & 1.9075 & $2.1221^{*}$ \\
\hline Spain & 0.0521 & 0.2123 & 0.0075 \\
\hline Sweden & 0.8785 & 0.1554 & 1.3689 \\
\hline Turkey & 0.0208 & 0.6542 & 0.8770 \\
\hline United Kingdom & 0.1691 & 0.4111 & 0.5214 \\
\hline United States & 0.0703 & 0.0133 & 0.0376 \\
\hline Significance denoted by $* * *$ at $1 \%, * *$ at $5 \%$ and * at $10 \%$ level. \\
\hline
\end{tabular}

In the same manner, Table 4 shows that while for Chile, Greece, Israel, and Korea there is Granger causality from Theil to union density, there exists Granger causality from EHII to 
union density for Germany, Greece, Israel, and New Zealand. Considering the causality relation, Tables 3 and 4 show that for Chile, Ireland, Japan, Norway, and Turkey, the causality is not just very strong but also valid at all lags analyzed.

Table 5: Directions of Causality for 24 OECD countries

\begin{tabular}{|c|c|}
\hline Australia & $U D \rightarrow E H I I$ \\
\hline Austria & No causality \\
\hline Belgium & No causality \\
\hline Canada & No causality \\
\hline Chile & $U D \rightarrow$ Theil, Theil $\rightarrow U D$ and $U D \rightarrow E H I I$ \\
\hline Denmark & No causality \\
\hline Finland & $U D \rightarrow E H I I$ \\
\hline France & No causality \\
\hline Germany & $E H I I \rightarrow U D$ \\
\hline Greece & Theil $\rightarrow U D$ and $E H I I \rightarrow U D$ \\
\hline Ireland & $U D \rightarrow$ Theil and $U D \rightarrow E H I I$ \\
\hline Israel & Theil $\rightarrow U D$ and $E H I I \rightarrow U D$ \\
\hline Italy & No causality \\
\hline Japan & UD $\rightarrow$ Theil \\
\hline Korea & Theil $\rightarrow U D$ \\
\hline Luxembourg & No causality \\
\hline Netherlands & No causality \\
\hline New Zealand & $U D \rightarrow$ Theil and $E H I I \rightarrow U D$ \\
\hline Norway & $U D \rightarrow E H I I$ \\
\hline Spain & $U D \rightarrow E H I I$ \\
\hline Sweden & No causality \\
\hline Turkey & UD $\rightarrow$ Theil \\
\hline United Kingdom & $U D \rightarrow E H I I$ \\
\hline United States & No causality \\
\hline
\end{tabular}

As Table 5 summarizes, 14 out of 24 OECD countries in question exhibit heterogeneous causality between union density and inequality. Eight countries have only one-way causality from union density to income inequality: Australia, Finland, Ireland, Japan, Norway, Spain, Turkey, and the UK. Other four countries, Germany, Greece, Israel, and Korea, have causality 
from inequality to union density. Finally, Chile and New Zealand are two countries with bidirectional causality.

Overall, these findings make three facts evident about the relationship between union density and pay/income inequality. First, the study yields substantial evidence for causality between union density and income inequality in a panel structure. Our findings that there exists causality only for 14 out of 24 countries in total does not contradict with the findings of the early studies that have time-series or panel data analysis. The difference in adopted method, time periods and set of countries prevents us from making a direct comparison with the early studies. In fact, it is plausible to argue that this study yields highly supportive evidence for the nexus of deunionzation-income inequality, providing substantial evidence for causality between the variables in question.

Second, considering detected causalities, it appears that the results are sensitive to how we measure inequality. Out of 14 countries, only for three countries (Chile, Ireland and Israel) does the causality exist for both inequality variables. At this point, it is worth recalling the difference between Theil and EHII. While the former is pay inequality in the manufacturing sector, the latter is computed by combining the former and the household income inequality set by Deininger-Squire (1996) to reflect household income inequality.

Third, our findings show that causality not only runs from union density to inequality (10 countries) but also the other way around (six countries). This is of importance, since the link from pay inequality toward unionization has not been received enough attention in the empirical literature. That is, these results provide supportive evidence for those who argue that not only 
does deunionization cause higher income inequality, but also inequality affects the incentive to join the unions (Acemoglu et al 2001; Checchi et al 2007).

\section{Conclusion}

The effect of deunionization resulted by globalization and changing technology on the distribution of wages has received significant attention by scholars as the neoliberal era has witnessed a remarkable pattern of declining union density and increasing income inequality across the OECD countries. Although there are a few studies which found positive or no relationship between union density and income inequality, the bulk of the available literature, both time series and panel data studies, provide substantial evidence on the negative impact of deunionization on the distribution of wages (and income).

The study contributed to this vast literature by examining the relationship in question by utilizing two alternative novel data sets for pay and income inequality, both provided by the University of Texas Inequality Project, and adopting a panel Granger causality method. This method allows us to investigate the existence of the relationship between union density and inequality measure variables without depending upon a restrictive a priori theory. Therefore, this approach allows us to study a higher number of countries for an extended time period.

Covering 24 OECD countries and a relatively wide range of time periods (i.e. 1963-2000) we analyze the relationship between union density and pay inequality and a proxy index for income inequality. Regardless of chosen lag structures, time periods, and sets of countries, overall findings show that there is substantial evidence on the existence of the relationship between union density and income inequality in a panel data context. Accordingly, the causality is detected for 14 out of the total 24 countries in question. While for Australia, Finland, Ireland, 
Japan, Norway, Spain, Turkey, and the UK there is significant Granger causality from union density to inequality, for Greece, Israel, and Korea the causality is from inequality to union density, and Chile and New Zealand present bidirectional causality. Also, it is worth mentioning that our results suggest that for Chile, Ireland, Japan, Norway, and Turkey, the causality is not just very strong but also valid at all lags that were analyzed. Considering the fact that there are six countries in which causality runs from inequality to union density, it is plausible to argue that not only does deunionization have a negative (as the previous literature shows) effect on the distribution of wages, but also increasing inequality affects the decision on union membership. This finding suggests that there is need to take into account bidirectional relationship between the variables in further analyses. Overall, our findings are highly consistent with the related literature in the sense that it made evident a statistically significant relationship between the variables in question with a different method.

In this study, we use three step testing process developed for balanced data sets by Hurlin and Venet (2001). In fact, it may be possible to adopt another method to consider an unbalanced panel data for our case, where one can analyze the relationship for a higher number of countries. This, however, could be an interest of further studies. 


\section{References}

Acemoglu, D., P. Aghion and G. L. Violante (2001) "Deunionization, Technical Change and Inequality", available at http://www.econ.nyu.edu/user/violante/Journals/CR_feb01.pdf

Alderson, Arthur S., and François Nielsen 2002. "Globalization and the Great U-Turn: Income Inequality Trends in 16 OECD Countries.American”. American Journal of Sociology. 107: 1244-1299.

Baccaro, Lucio. 2008. "Labour, Globalization and Inequality: Are Trade Unions Still Redistributive?” International Institute for Labour Studies Discussion Paper 192/2008.

Baltagi, B.H. (2005), Econometric analysis of panel data, New York: Wiley.

Blanchflower, D. G. (2006) “A Cross-Country Study of Union Membership”, IZA DP No. 2016.

Blanchflower, David G and Alex Bryson (2003). "What effect do unions have on wages now and would “what do unions do?” be surprised?", NBER Working paper 9973.

Bradley, D., E. Huber, S. Moller, et al. (2003). "Distribution and Redistribution in Postindustrial Democracies." World Politics 55: 193-228.

Breitung, J. (2000), “The Local Power of Some Unit Root Tests for Panel Data”, in Baltagi, B. ed.), Advances in Econometrics, vol. 15: Nonstationary Panels, Panel Cointegration, and Dynamic Panels, Amsterdam: JAI Press, pp. 161-178.

Breitung, J. and S. Das (2005) "Panel unit root tests under cross-sectional dependence", Statistica Neerlandica, 59: 414-433.

Calderon, C., A. Chong and R. Valdés (2004) "Labor Market Regulations and Income Inequality: Evidence for a Panel of Countries”, Inter-American Development Bank. 
Card, David (1996) "The Effects of Unions on the Structure of Wages: A Longitudinal Analysis.” Econometrica 64 (July 1996): 957-79.

Card, David 1998. "Falling Union Membership and Rising Wage Inequality. What's the connection?" NBER Working Paper 6520. Cambridge, MA.

Card, D. (2001) “The Effect of Unions on Wage Inequality in the U.S. Labor Market", Industrial and Labor Relations Review, Vol. 54, No. 2 (Jan., 2001), pp. 296-315.

Card, David, Thomas Lemieux and W. Craig Riddell (2004) "Unions and Wage Inequality, Unions and wage inequality.” Journal of Labor Research 25(4): 519-559.

Carlin, Wendy and David Soskice (1990) Macroeconomics and the Wage Bargain: A Modern Approach to Employment, Inflation and the Exchange Rate, New York: Oxford University Press.

Chamberlain, Gary (1994) "Quantile Regression, Censoring and the Structure of Wages," in Proceedings of the Sixth World Cogress of the Econometrics Society, Barcelona, Spain, ed. by Christopher A. Sims, and Jean-Jacques La_ont, pp. 179\{209. Cambridge University Press, New York.

Checchi, Daniele, Jelle Visser and Herman G. van de Werfhorst (2007) "Inequality and Union Membership: The Impact of Relative Earnings Position and Inequality Attitudes”, IZA DP No. 2691.

Checchi, Daniele and Visser, Jelle (2005) "Pattern Persistence in European Trade Union Density: A longitudinal analysis 1950-1996”, European Sociological Review, 21, 1-21.

Checci, Daniele and Cecilia Garcia-Penalosa (2008) "Labour Market Institutions and Income Inequality," Paper presented to the Economic Policy Panel meeting (Lubjana 1819/4/2008). 
Checci, Daniele and Laura Pagani (2004) "The Effects on Unions on Wage Inequality: The Italian Case in the 1990s" IZA DP No: 1385.

Chintrakarn, P. (2011) "Labour Unions and Income Inequality: Evidence from US States," Journal of Applied Sciences, 11(20): 3530-3533.

Choe, J. I. (2003) "Do foreign direct investment and gross domestic investment promote economic growth?", Review of Development Economics, 7: 44-57.

Choi, I. (2001) "Unit Root Tests for Panel Data", Journal of International Money and Finance, 20: $249-272$.

Deininger, K. and Squire, L. (1996) “A New Data Set Measuring Income Inequality” World Bank Economic Review 10: 565-591.

DiNardo, John, Nicole M. Fortin, and Thomas Lemieux. "Labor Market Institutions and the Distribution of Wages, 1973-1992: A Semi-Parametric Approach.” Econometrica 64 (September 1996): 1001-1044.

Doerrenberg, Philipp and Andreas Peichl (2012). The Impact of Redistributive Policies on Inequality in OECD counties, IZA Discussion Paper No. 6505.

Ebbinghaus, Bernhard, Göbel, Claudia, and Koos Sebastian (2011) 'Social capital, 'Ghent' and workplace contexts matter: Comparing union membership in Europe," European Journal of Industrial Relations, 17, 107-124.

Erdil, E. and I. H. Yetkiner (2009) "The Granger-causality between health care expenditure and output: a panel data approach,” Applied Economics, 41(4): 511-518 
Frandsen, B. R. (2012) "Why Unions Still Matter: The Effects of Unionization on the Distribution of Employee Earnings," available at http://www.ewissl.pitt.edu/econ/files/seminars/120224_sem_Brigham\%20Frandsen.pdf

Freeman, Richard B. (1980) "Unionism and the Dispersion of Wages" Industrial and Labor Relations Review 34(1): 3-23.

Freeman, Richard B. (1984) "Longitudinal Analyses of the Effects of Trade Unions," Journal of Labor Economics, 2:1-26.

Freeman, Richard B. and James L. Medoff. What Do Unions Do? New York: Basic Books, 1984.

Galbraith, J. K. (2009) "Inequality, Unemployment and Growth: New Measures for Old Controversies," Journal of Economic Inequality 7(2):189-206.

Galbraith, J. K. (2012) Inequality and Instability: A Study of the World Economy Just Before the Great Crisis, Oxford University Press.

Galbraith, J. and Conceição, P. (2001) Towards a new Kuznets hypothesis: theory and evidence on growth and inequality. in Inequality and Industrial Change: A Global View, edited by J. Galbraith and M Berner Cambridge University Press: Cambriedge.

Galbraith, J. K. ve Kum, H. (2005). "Estimating the inequality of households incomes: toward a dense and consistent global data set," Review of Income and Wealth, 51(1): 115-143.

Georgiou, Miltiades N. (2012) "Trade Union Power and Income Distribution: A Panel Data Analysis for Western Europe (1999-2008)," available at http://papers.ssrn.com/sol3/papers.cfm?abstract_id=2181429

Granger, C. W. J. (1969) "Investigating causal relations by econometric models and crossspectral methods," Econometrica, 37: 424-438. 
Greene, W. H. (2008), Econometric Analysis, 6. ed, Pearson Prentice Hall: Upper Saddle River, New York.

Hansen, H. and Rand, J. (2006) "On the Causal Links between FDI and Growth in Developing Countries," The World Economy, 29 (1): 21-41.

Hoffmann, R., C. G. Lee, B. Ramasamy and M. Yeung (2005) "FDI and Pollution: A Granger Causality Test Using Panel Data," Journal of International Development, 17(3): 311317.

Holtz-Eakin, D., Newey, W. and Rosen, H. (1985), “Implementing causality tests with Panel data, with an example from local public finance", NBER Technical Paper Series No. 48.

Holtz-Eakin, D., Newey, W. and Rosen, H. (1988), "Estimating vector autoregressions with panel data”, Econometrica, 56, 1371-95.

Hood III, M.V., Q. Kidd and I. L. Morris (2008), "Two Sides of the Same Coin? Employing Grange Causality Tests in a Time Series Cross-Section Framework," Political Analysis 16: $324-344$.

Hsiao, C. (1989), "Modeling Ontario regional electricity system demand using a mixed fixed and random coefficients approach", Regional Science and Urban Economics 19:565-87.

Hurlin, C. (2004a), "Testing Granger causality in heterogeneous panel data models with fixed coefficients," mimeo, University of Orleans.

Hurlin, C. (2004b), "A note on causality tests in panel data models with random coefficients," mimeo, University of Orleans. 
Hurlin, C. and Venet, B. (2001) "Granger causality tests in panel data models with fixed coefficients”, Eurisco working paper no. 2001-09, University of Paris-Dauphine.

Im, K.S., Pesaran, M.H., Shin, Y. (2003) "Testing for Unit Roots in Heterogeneous Panels," Journal of Econometrics, 115: 53-74.

Judson, R.A. and Owen, A.L. (1999) "Estimating dynamic panel data models: a guide for macroeconomists," Economic Letters 65: 9-15.

Kahn, Lawrence M. (2000) "Wage Inequality, Collective Bargaining, and Relative Employment from 1985 to 1994: Evidence from Fifteen OECD Countries”, The Review of Economics and Statistics 82(4): 564-579.

Kaufman, B. E. (2002) "Models of Union Wage Determination: What Have We Learned Since Dunlop and Ross?" Industrial Relations 41(1): 110-158.

Koeniger, W., M. Leonardi and L. Nunziata (2007) "Labour Market Institutions and Wage Inequality" Industrial and Labor Relations Review 60(3): 340-56.

Kiviet, J. F. (1995), “On bias, inconsistency and efficiency of various estimators in dynamic panel data models" Journal of Econometrics 68, 53-78.

Lemieux, Thomas (1993) "Unions and Wage Inequality in Canada and the United States" available at http://www.nber.org/chapters/c11146

Lemieux, Thomas (1998) "Estimating the Effects of Unions on Wage Inequality in a Panel Data Model Comparative Advantage and Nonrandom Selection" Journal of Labor Economics 16(2): 261-291.

Levin, A., Lin, C. F., and Chu, C. (2002) "Unit Root Tests in Panel Data: Asymptotic and FiniteSample Properties" Journal of Econometrics, 108: 1-24. 
Lin, E. S. and Ali, H. E. (2009) "Military Spending and Inequality: Panel Granger Causality Test" Journal of Peace Research 46(5): 671-685.

Maddala, G. S. and S. Wu (1999) “A Comparative Study of Unit Root Tests with Panel Data and A New Simple Test," Oxford Bulletin of Economics and Statistics 61: 631-652.

Metcalf, David, Kristine Hansen, and Andy Charlwood 2001. "Unions and the Sword of Justice: Unions and pay systems, pay inequality, pay discrimination and low pay" National Institute Economic Review 176: 61-75.

Nair-Reichert, U. and Weinhold, D. (2001) "Causality tests for cross-country panels: a new look at FDI and economic growth in developing countries" Oxford Bulletin of Economics and Statistics 63: 153-71.

Nickell, S. (1981) "Biases in dynamic models with fixed effects" Econometrica 49: 1399-416.

OECD (2011) "Divided we stand: why inequality keeps rising" www.oecd.org

OECD (2012) "Inequality in labour income - What are its drivers and how can it be reduced?" OECD Economics Department Policy Notes, No. 8. January 2012.

Pontusson, J., D. Rueda and C. R. Way (2003) "Comparative Political Economy of Wage Distribution: The Role of Partisanship and Labour Market Institutions" British Journal of Political Science 32: 281-308.

Rueda, David, and Jonas Pontusson (2000) "Wage Inequality and Varieties of Capitalism" World Politics 52(3): 350-383.

Schmitt, John and Alexandra Mitukiewicz (2012) "Politics Matter: Changes in Unionization Rates in Rich Countries, 1960-2010” Industrial Relations Journal 43, 260-280. 
Schnabel, Claus (2012) "Union membership and density: Some (not so) stylized facts and challenges" Diskussionspapiere, Universität Erlangen-Nürnberg, Lehrstuhl für Arbeitsmarkt- und Regionalpolitik, No. 81, http://hdl.handle.net/10419/66786

Schnabel, Claus and Wagner, Joachim (2007) "Union density and determinants of union membership in 18 EU countries: evidence from micro data, 2002/03" Industrial Relations Journal 38, 5-32.

Stennek, Johan (2012) "Why Unions Reduce Wage Inequality: A Model of Union Formation and Goal Setting" available at http://ideas.repec.org/p/hhs/gunwpe/0539.html

Theil H. (1972) Statistical Decomposition Analysis: With Applications in the Social and Administrative Sciences, Amsterdam-London: North Holland Publishing Company.

UTIP (University of Texas Inequality Project), http://utip.gov.utexas.edu/

Utlu, S., Ispiroglu, F. and Elveren, A. Y (mimeo) “The Effect of Unions on Wage Inequality: Evidence from Turkey"

Visser, Jelle (2006) "Union membership statistics in 24 countries" Monthly Labor Review 129: $38-49$.

Volscho, Thomas W. (2008) 'Neoliberalism's Triumph? Falling Union Density, Falling Minimum Wages, and Rising Income Inequality in the United States, 1980-2000”, In: Income Distribution: Inequalities, Impacts and Incentives .Editor: Irving H. Wadell, pp. 99-117, Nova Science Publishers.

Volscho, T. W., and Fullerton, A. S. (2005) "Metropolitan earnings inequality: Union and government-sector employment effects" Social Science Quarterly 86: 1324-1337. 
Wallerstein, Michael (1999) "Wage-Setting Institutions and Pay Inequality in Advanced Industrial Societie" American Journal of Political Science 43: 649-80.

Weinhold, D. (1996) "Investment, growth and causality testing in panels" Economie et Prevision 126: $163-75$.

Weinhold, D. (1999) "A dynamic 'fixed effects' model for heterogeneous panel data" Unpublished Manuscript, London School of Economics.

Western, Bruce and Jake Rosenfeld (2011) "Unions, Norms, and the Rise in U.S. Wage Inequality" American Sociological Review 76(4): 513-537. 


\section{Appendix}

Table A1: Descriptive Statistics for the Variables

\begin{tabular}{|c|c|c|c|c|c|c|c|c|c|c|c|c|}
\hline & \multicolumn{4}{|c|}{ Union Density } & \multicolumn{4}{|c|}{ EHII } & \multicolumn{4}{|c|}{ Theil } \\
\hline & \multicolumn{2}{|c|}{$1963-2000$} & \multicolumn{2}{|c|}{ 1986-1998 } & \multicolumn{2}{|c|}{$1963-2000$} & \multicolumn{2}{|c|}{ 1986-1997 } & \multicolumn{2}{|c|}{ 1963-1999 } & \multicolumn{2}{|c|}{ 1986-1998 } \\
\hline & mean & std & mean & std & mean & std & mean & std & mean & std & mean & std \\
\hline Australia & 0.425 & 0.075 & 0.365 & 0.052 & 0.337 & 0.025 & 0.361 & 0.017 & 0.011 & 0.003 & 0.014 & 0.003 \\
\hline Austria & 0.533 & 0.093 & 0.444 & 0.042 & 0.351 & 0.011 & 0.354 & 0.004 & 0.018 & 0.005 & 0.019 & 0.005 \\
\hline Belgium* & & & 0.538 & 0.016 & & & 0.372 & 0.009 & & & & \\
\hline Canada & .336 & 0.035 & 0.354 & 0.023 & 0.360 & 0.012 & 0.371 & 0.004 & 0.019 & 0.003 & 0.022 & 0.001 \\
\hline Chile & & & 0.164 & 0.023 & & & 0.456 & 0.019 & & & 0.075 & 0.013 \\
\hline Denmark & & & 0.761 & 0.011 & & & 0.308 & 0.005 & & & 0.007 & 0.001 \\
\hline Finland & 0.649 & 0.136 & 0.763 & 0.041 & 0.317 & 0.016 & 0.323 & 0.010 & 0.011 & 0.001 & 0.010 & 0.001 \\
\hline France & & & 0.099 & 0.014 & & & 0.353 & 0.005 & & & 0.015 & 0.001 \\
\hline Germany & 0.324 & 0.029 & 0.312 & 0.030 & 0.328 & 0.013 & 0.334 & 0.008 & 0.011 & 0.002 & 0.012 & 0.002 \\
\hline Greece & & & 0.339 & 0.033 & & & 0.405 & 0.023 & & & 0.031 & 0.004 \\
\hline Ireland & 0.488 & 0.044 & 0.467 & 0.027 & 0.383 & 0.028 & 0.394 & 0.018 & 0.031 & 0.025 & 0.042 & 0.025 \\
\hline Israel & & & 0.659 & 0.099 & & & 0.423 & 0.006 & & & 0.065 & 0.006 \\
\hline Italy & & & 0.386 & 0.014 & & & 0.361 & 0.018 & & & 0.018 & 0.003 \\
\hline Japan & 0.300 & 0.047 & 0.250 & 0.018 & & & & & 0.033 & 0.015 & 0.042 & 0.019 \\
\hline Korea & 0.137 & 0.021 & 0.142 & 0.025 & 0.392 & 0.022 & 0.368 & 0.005 & 0.028 & 0.007 & 0.021 & 0.003 \\
\hline Luxembourg & & & 0.457 & 0.028 & & & 0.346 & 0.004 & & & 0.016 & 0.003 \\
\hline Netherlands & 0.314 & 0.059 & 0.250 & 0.008 & .328 & 0.015 & 0.333 & 0.014 & 0.010 & 0.002 & 0.009 & 0.001 \\
\hline New Zealand & & & 0.381 & 0.121 & & & 0.380 & 0.022 & & & 0.027 & 0.008 \\
\hline Norway & 0.565 & 0.020 & 0.571 & 0.011 & 0.323 & 0.014 & 0.334 & 0.014 & 0.009 & 0.001 & 0.009 & 0.000 \\
\hline Spain & & & 0.143 & 0.029 & & & 0.374 & 0.034 & & & 0.030 & 0.003 \\
\hline Sweden & 0.764 & 0.059 & 0.817 & 0.015 & 0.280 & 0.011 & 0.280 & 0.009 & 0.004 & 0.001 & 0.004 & 0.001 \\
\hline Turkey & & & 0.183 & 0.040 & & & 0.449 & 0.020 & & & 0.059 & 0.018 \\
\hline $\begin{array}{l}\text { United } \\
\text { Kingdom }\end{array}$ & 0.409 & 0.058 & 0.370 & 0.046 & 0.299 & 0.036 & 0.331 & 0.028 & 0.015 & 0.002 & 0.018 & 0.001 \\
\hline United States & 0.208 & 0.056 & 0.152 & 0.011 & 0.370 & 0.012 & 0.381 & 0.002 & 0.025 & 0.003 & 0.027 & 0.001 \\
\hline
\end{tabular}

(*): Belgium's union density covers 1986-1997. 
Figure A1: Testing Procedure for a Panel Granger Causality Test based on Hurlin and Venet (2001)

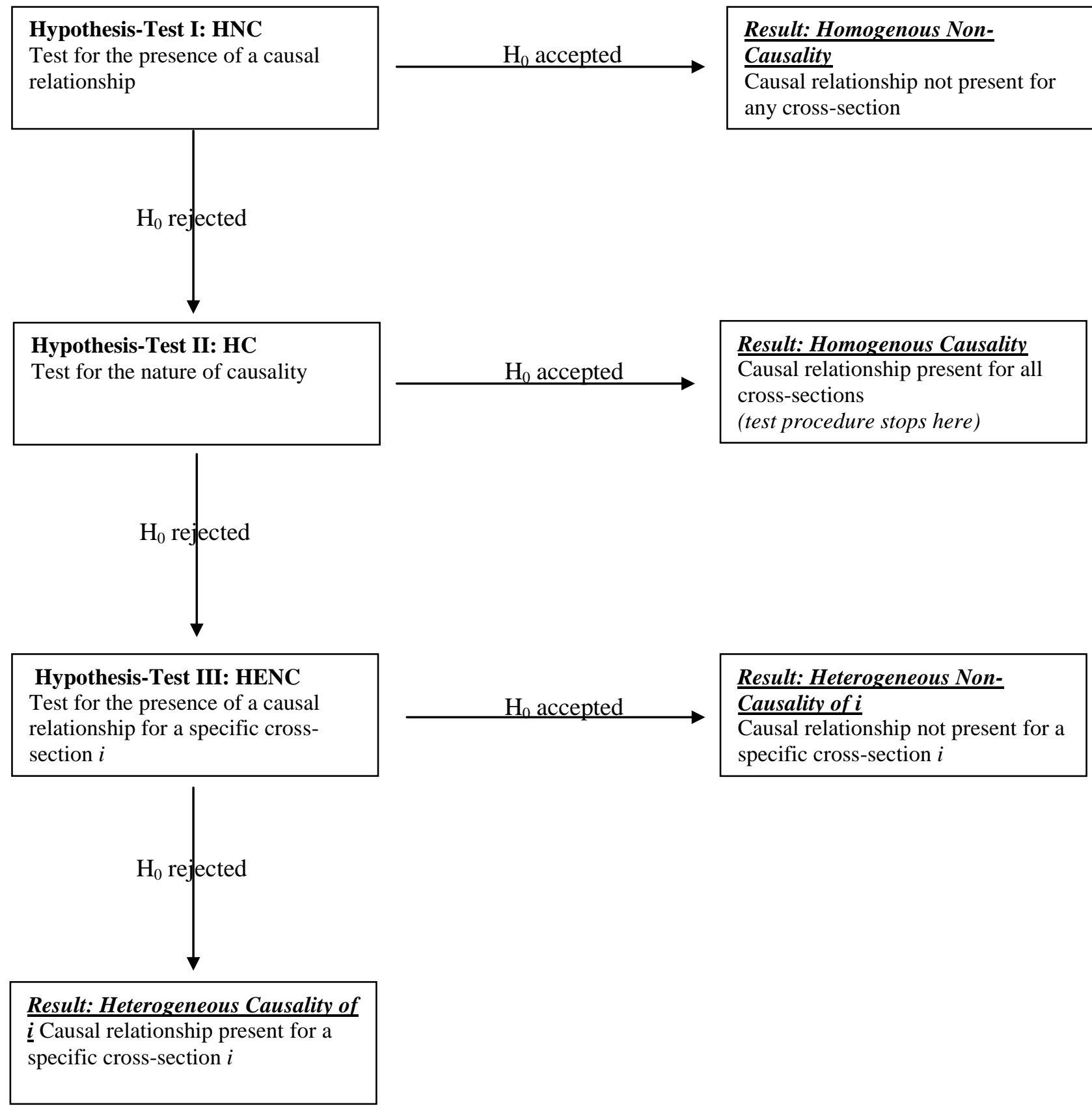

